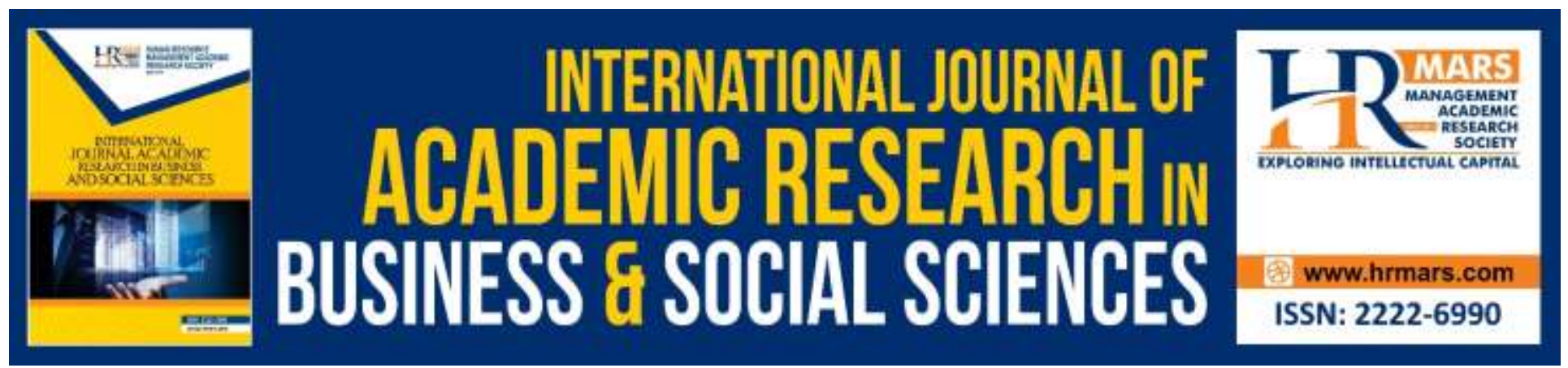

\title{
Linking between E-government and Money Laundering: The Mediating Role of Compliance Unit
}

\section{Khaled Abdel Kader Alomari}

To Link this Article: http://dx.doi.org/10.6007/IJARBSS/v10-i2/6919

DOI:10.6007/IJARBSS/v10-i2/6919

Received: 30 December 2019, Revised: 10 January 2020, Accepted: 30 January 2020

Published Online: 13 February 2020

In-Text Citation: (Alomari, 2020)

To Cite this Article: Alomari, K. A. K. (2020). Linking between E-government and Money Laundering: The Mediating Role of Compliance Unit. International Journal of Academic Research in Business and Social Sciences, 10(2), 179-194.

\section{Copyright: (C) 2020 The Author(s)}

Published by Human Resource Management Academic Research Society (www.hrmars.com)

This article is published under the Creative Commons Attribution (CC BY 4.0) license. Anyone may reproduce, distribute, translate and create derivative works of this article (for both commercial and non-commercial purposes), subject to full attribution to the original publication and authors. The full terms of this license may be seen

at: http://creativecommons.org/licences/by/4.0/legalcode

$$
\text { Vol. 10, No. 2, 2020, Pg. } 179-194
$$

Full Terms \& Conditions of access and use can be found at http://hrmars.com/index.php/pages/detail/publication-ethics 


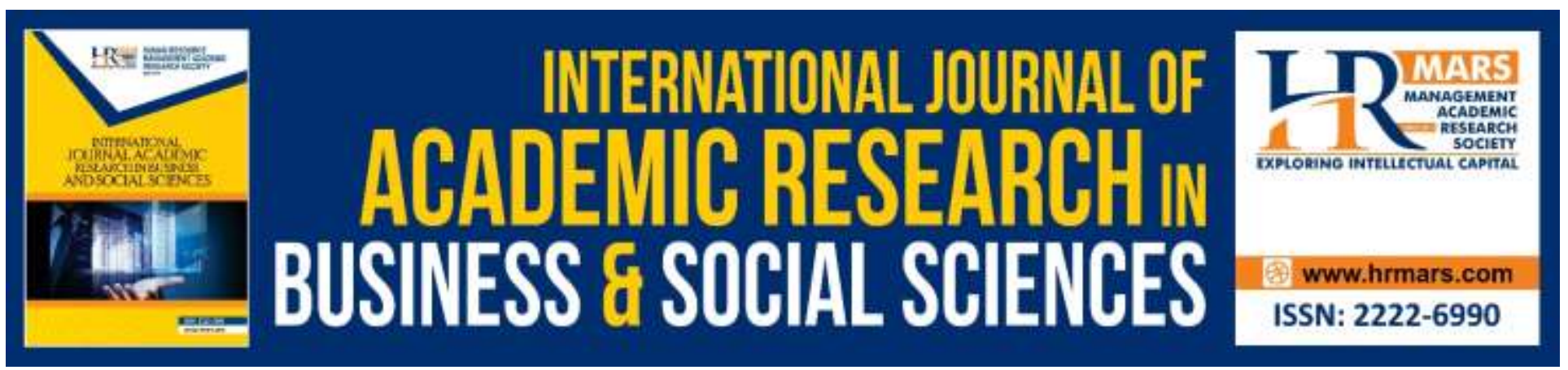

\title{
Linking between E-government and Money Laundering: The Mediating Role of Compliance Unit
}

\author{
Khaled Abdel kader Alomari \\ College of Business, Jadara University, Irbid, Jordan \\ E-mail: khaledabdalgaderalomari@gmail.com
}

\begin{abstract}
The aim of this study is to identify the role of compliance unit between e-government and money laundering in the Jordanian central bank. The samples consist of 142 employers of the central bank from different Units. They were selected randomly and analyzed by AMOS. Results showed that there is an impact significance level for the compliance unit between e-government and money laundering. A result also showed that there is an impact of significance between the e-government against money laundering. According to the study results study recommend the following: the need to work on a commitment plan for all the bank employees on their different levels and positions in responsibility positions in the basic principles associated with fighting money laundering methods in terms of preventing such operations of happening, and discover it if it occurred.
\end{abstract}

Keywords: E-government, Money Laundering, Compliance Unit, Jordanian Central Bank.

\section{Introduction}

E-government is a new concept that has emerged as a result of technological progress, it has developed in recent years. There has been a revolution in the speed of data transfer and exchange, and the volume of information stored and the ease of communication, due to the increasing demand for using the computer with its various applications (Aljawarneh \& Al-Omari, 2018). Information is through electronic means, and this is not only for organizations and the business world, but extends to all categories of society and its individual and collective segments (Aljawarneh \& Atan, 2018). The e-Government relies on a variety of modern technology means for multi-computer networks and wide and extensive, e-mail and other electronic applications that assist in the implementation of business tasks (Ostašius \& Laukaitis, 2015). It is necessary and appropriate for the Internet to be a safe technical technique, achieving an acceptable degree of security on the network is one of the most important requirements to carry out its work, and become a problem of information security more specific to cash transfers in various forms (lonescu, 2015). However, the trend towards information security other than the acceptance of the Internet as a safe mode of finance and exchange is increasing day after day because of the widespread interest in its security and has 
INTERNATIONAL JOURNAL OF ACADEMIC RESEARCH IN BUSINESS AND SOCIAL SCIENCES Vol. 10, No. 2, Feb, 2020, E-ISSN: 2222-6990 @ 2020 HRMARS

become rival by the giant companies through the increasing successes in the field of security and information technology (Al-Jawarneh, 2016).

As well as legislative and regulatory interest to provide protection and control over data and Internet information, including banking and banking information (Anthes, 2015). E-government is one of the modern concepts and technologies that have been associated with the revolution of information and communication technology, and their impact on the government sector and on this basis it provides government services to citizens and the business community (Al-Omari, et al., 2020; Fathima \& Ragel, 2015).

The use and investment of modern technology, and modern communication networks, with the aim of raising the performance competencies of government agencies and achieving the required efficiency in dealing (Fathima \& Ragel, 2015). After this tremendous development in the world of electronic communications, modern electronic communications have become one of the most important means used in the implementation of money laundering operations, especially in the stages of recruitment and integration, such as electronic transfer of funds and payment of bills, becoming the most common and easiest way to carry out money laundering, Beyond the borders of one state, and calls for concerted international and governmental efforts to combat it (Jun et al, 2014). The money laundering process is also one of the forms of transcontinental crimes and has a negative impact on the societies in which they spread, in terms of the size, structure and distribution of national income, saving and unemployment rates, investment rates, structure, climate and resource allocation. Deposit of securities and the banking system (judges, 2010). Therefore, the crimes of money laundering are considered one of the most serious crimes of the economic age. It is also an examination of the ability of legal rules and legislations to effectively combat this phenomenon, the crime activities and its new patterns, in order to give it legal status (Seo \& Hasan, 2015). Wherefore this study aimed at the proffering a solution whereby the compliance unit in conjunction and corporation with e-government can fight and combat money laundering (AlJawarneh, 2020). The crime of money laundering is considered as other economic crimes committed by persons whose characteristics do not match the criminal characteristics identified by conventional criminology and punishment theories. Given the importance of this crime and the difficulty of combating it, the problem of this research is crystallized in answering the following main question: Does compliance unit mediate the relationship between e-government and money laundering? It is divided into the following questions: Q1: Does e-government has a positive impact on money laundering? Q2: Does e-government has a positive impact on compliance unit? Q3: Does compliance unit has a positive impact on money laundering?

The importance of study is to highlight the link between e-government and money laundering through compliance unit, which entails a set of economic, financial, social and political effects. This importance lies in the money laundering operations that are growing globally and continuously. Here in Jordan, they are threatening national economy due to the volatile environment in neighboring countries and unknown migration of money. Defining this phenomenon in terms of concept, procedures, methods and international efforts to combat it. Where the study sought to identify the role of compliance unit as a mediator between e-government and money laundering in terms of providing organizations with lists of names and information about persons and institutions associated with money laundering, terrorist financing and fraud, these systems monitor banking operations in financial institutions to detect money laundering, terrorist financing or fraud. 


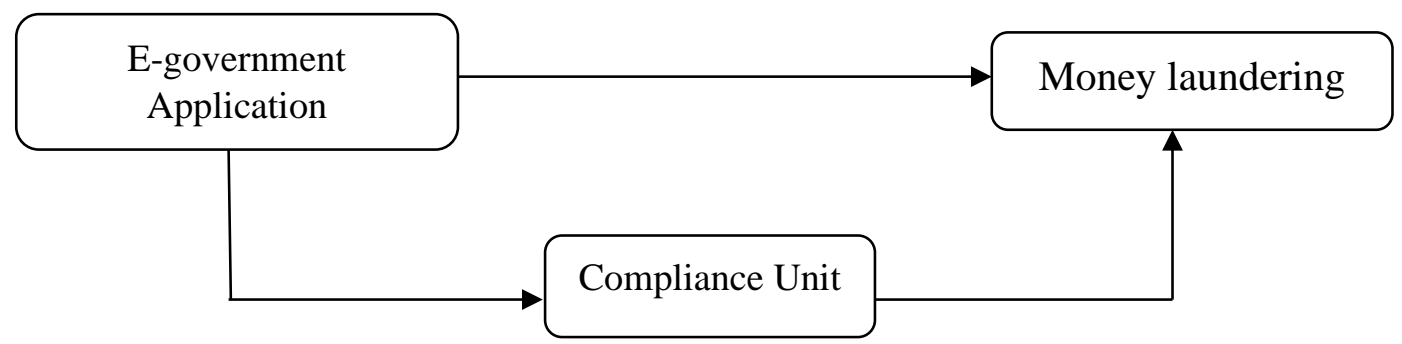

E-government, being an independent variable, is not influenced by any of the factors in the above model; however, it contributes to the both factors such as: compliance unit and money laundering.

\section{Literature Review \\ E-government}

E-Government (e-Gov.) is considered to have emerged in the late 1990s, meanwhile history has it that computing in government organizations can be traced back to the beginning of computer innovation. A literature on "IT in government" goes back at least to the 1970s (Kraemer, et al, 1978; Danziger and Andersen, 2002). This literature has to do with IT use in governmental operations, while the recent e-Government literature has a lot to do with external use, such as services to the citizens (Ho, 2002).

According to Henriksen (2005) while some earlier e-Government computer issues, such as office automation, may not be highly relevant to research today, many issues are, for example decision making, service processes, and values. E-Government go beyond services to the citizen to include organizational change and the role of government. Therefore, the two strands of literature need to be considered together as the basis of the e-Government field. Gore, (1993); Salem, (2003) posits that E-Government started as a practitioner field, basically bringing practitioners together who are struggling to meet the new challenges of the Internet medium by implementing new systems creatively. The dominant definition of e-Government emerged from fields of practice. Around the turn of the millennium, governments across the globe set up definitions as basis for national strategies to achieve excellence based on use of Internet technology. (Grönlund, 2002). Businessmen and women, if achieving a better level of services for citizens is still and will remain the ultimate goal of public administration, and if the needs and requirements of these citizens are multiple and continuously renewable, the change and planned development must exist for The emergence of the term e-government, which is an integral part of e-management as an integrated system, space and digital clouds that includes both e-business to indicate the electronic management of business, egovernment to indicate the electronic management of government work in various government sectors (Sutopo et al., 2017).

\section{Money Laundering}

The underground economy is defined as invisible, occult, parallel, illegal, informal, etc. Ereminaitė, (2014). As a phenomenon parallel to the real economy, seen as mandatory in others it was previously denied because of its elements that are manifested almost chaotic, being difficult to study, it could not be ignored because the underground activities were manifested in the global economy. Money laundering is a financial crime that might negatively impact the stability of the economy, especially 
on investment funding (Jack, 2013). Money laundering is typically described as the ownership of property obtained through illegal to legitimate sources (Conyers \& Pearman, 2013). Also, Money laundering is the process of converting dirty money into clean funds by using a high-ranking employees in large corporations divert money to personal accounts, tax evasion, prostitution, or drug trafficking. There are many ways to launder money; the best ways to launder money are through the using of financial institutions, businesses and companies that serve as a front for receiving the illicit funds. (Khrawish, 2014). Underground economy is continuously evolving as it is accepted in some countries, fought against in the developed countries. Fraud, trafficking in arms and drugs, terrorism, corruption, money laundering is conducted greatly due to the existence of increasingly effective methods with a view to increase earnings. These gains have led the international crime organizations to abandon violent competition and to form occult alliances. Generally, it is cited that the activities of underground economy have experienced large growth, as it is stimulated by the phenomenon of globalization. Nations constantly lose elements of their sovereignty in the fight against organized groups, the latter showing that they know how to use legal loopholes, transferring amounts derived from illegal activities in countries that offer incentives. Due to the gravity of this phenomenon and its negative effects on society, many economic and legal researchers have studied this phenomenon. (Daniali, 2014). It is one of the most serious crimes of the modern era of the economy, which represents the real challenge facing the financial and business institutions (Pok et al, 2014). It is one of the forms of transnational crimes that have a negative impact on the societies in which they are spread, in terms of the size, structure and distribution of national income, Investment and rates, and their negative effects on the stock market and the banking system (MCA et al., 2014).

\section{Compliance Unit}

This is the unit whose activities are to counter the activities or effects of money laundry in the society. Compliance unit also can be referred to anti money laundry AML, which is the combinations of both cyber and non-cyber units in the countering of activities of money launderers. This study aims at encouraging the funding of investments and it protects from money laundry by compliance unit which includes fighting the: terrorism financing, drug trafficking, weapons trafficking and money that result from bribery, exploitation of public office, commissions and trading on black market. Also, the importance of compliance unit is to find the appropriate solutions which relating to money laundering that include customer due diligence, suspicious activity monitoring, know your customer, case management, and watch-list filter. Finally, this study is considered the first one in Jordan (Ereminaitė, 2014).

Due money laundering effects on economic growth and financial stability. As the financial institutions (which also has a link to compliance unit) play an important role in financing the investments, it requires them to fight money laundering by checking account opening, accepting money on deposit and give the loans. This information was made to reduce money laundering, financial crime and terrorist financing (Ayodegi, 2011). Subbotina (2008) to combat money laundering cooperation between different financial institutions, especially banks and countries should be promoted. A lot of country's economy was affected negatively by money laundering, financial crime and terrorist financing. Therefore, the ability of cash flows between countries has many benefits, if these countries were able to fight money laundering and financial crime and terrorist financing because the fight of money laundering and financial crime and terrorist financing will reduce the effects negatively in 
INTERNATIONAL JOURNAL OF ACADEMIC RESEARCH IN BUSINESS AND SOCIAL SCIENCES Vol. 10, No. 2, Feb, 2020, E-ISSN: 2222-6990 @ 2020 HRMARS

regards of funding investment, jobs and new technologies. On the other hand, developing countries should establish offshore financial centers as vehicles for economic development and reduce the crime and corruption (Bartlett 2002). According to Tanzi (1996) Due to the positive effect between anti-money laundering and the activities of the international economy and international financial markets, the globalization of economic activities works to lower the cost of anti-money laundering.

\section{E-government, Compliance Unit \& Money Laundering}

E-government plays a vital role when it comes to the phenomenon money laundry with its use of cyber technology in different ways to check the activities of its citizens. E-government is an arm or body of the government whose governance draws its power from the internet, its activities is cyber based. Thus it fights crime via the internet. Money laundering is a financial crime that might negatively impact the stability of the economy, especially on investment funding Jack, (2013) money laundering is typically described as the ownership of property obtained through illegal to legitimate sources (Conyers \& Pearman, 2013). Also, Money laundering is the process of converting dirty money into clean funds by using a high-ranking employees in large corporations divert money to personal accounts, tax evasion, prostitution, or drug trafficking. There are many ways to launder money; the best ways to launder money are through the using of financial institutions, businesses and companies that serve as a front for receiving the illicit funds. (Khrawish, 2014). A lot of economy was affected negatively by money laundering, financial crime and terrorist financing. There is a positive effect between anti-money laundering and the activities of the international economy and international financial markets because the globalization of economic activities works to lowest the cost of antimoney laundering. Although the facility with which dirty/money can now be laundered internationally this works to lowest the cost of anti-money laundering finally, Tanzi, 1996 found a positive relationship between globalization e.i e-Government and money laundering, as well as some to the economic implications of large-scale money laundering. (Khrawish, 2014). Due money laundering effects on economic growth and financial stability as the financial institutions (which also have a link to compliance unit) play an important role in financing the investments, it requires them to fight money laundering by checking account opening, accepting money on deposit and give the loans (Al-Omari, et al., 2018). This information was made to reduce money laundering, financial crime and terrorist financing (Ayodegi, 2011).

\section{$\mathrm{H}_{1}$ : E-government has a Positive Impact on Money Laundering}

E-government plays a vital role when it comes to the phenomenon money laundry and thus it has a great link and relationship with the compliance unit e.i anti-money laundering (Chen, 2008). EGovernment in various ways has influenced the role of the compliance unit positively with its use of cyber technology in different ways to check the activities of its citizens. E-government is an arm or body of the government whose governance draws its power from the internet, its activities is cyber based. Thus it fights crime via the internet. Chen, (2008) Compliance unit been the unit whose is to watch and counter the activities or effects of money laundry in the society, has a lot to do with eGovernment as they both work hand in hand to fight corruption in the society. Compliance unit also can be referred to anti money laundry AML, which is the combinations of both cyber and non-cyber units in the countering of activities of money launderers through the impact of e-Government. Chen, 2008) 
INTERNATIONAL JOURNAL OF ACADEMIC RESEARCH IN BUSINESS AND SOCIAL SCIENCES Vol. 10, No. 2, Feb, 2020, E-ISSN: 2222-6990 @ 2020 HRMARS

E-governance cannot be seen as a single configuration of meaning, power, and norms. The digitization of governance is as much cultural and interpretive as well as technical and objective (Chen, 2008). It does not automatically give impact to the enhancement of public service quality. Therefore, a good service by e-government entirely depends on the public service orientation as well. Knowledge of the factors will enable government agencies to develop online services to meet the needs of their citizens (Carter, 2005). According to Stewart, (1987) the danger is that services provided to the public are without regard for the views of those for whom the services are delivered Henriksen (2005) cited that this literature has to do with IT use in governmental operations, while the recent e-Government literature has a lot to do with external use, such as services to the citizens while some earlier e-Government computer issues, such as office automation, may not be highly relevant to research today, many issues are, for example decision making, service processes, and values. E-Government go beyond services to the citizen to include organizational change and the role of government. Therefore, the two strands of literature need to be considered together as the basis of the e-Government field Henriksen (2005).

According to (Ahmad, 2008, p: 79) "Producing and distribution information within 24 hours/day and seven days/week in a manner that is based on fulfillment of needs of citizens and business".

\section{H2: E-government has a Positive Impact on Compliance Unit}

Compliance basically is adherence to set laws and regulations. Due to the enormous effect of money laundering on the economic growth and financial stability. As the financial institutions (which also has a link to compliance unit) play an important role in financing the investments, it requires them to fight money laundering by checking account opening, accepting money on deposit and give the loans. These information were made to reduce money laundering, financial crime and terrorist financing through the implementations of the compliance unit (Ayodegi, 2011). Money laundering is a financial crime that might negatively impact the stability of the economy, especially on investment funding (Jack Law Group, 2013); money laundering is typically described as the ownership of property obtained through illegal to legitimate sources (Conyers \& Pearman, 2013). According to Cotterill (2001), Money launderers use certain techniques to convert dirty money into clean money, which include conversion of cash into other assets that could easily be transferred, establishment of business in abroad, changing the currency of cash, altering the amount of different security holdings, circulation of money between different banks and using shell companies. Cotterill (2001) Money laundering could be reduced by implementing anti money-laundering techniques, employee training maintaining proper records of customers, proper monitoring of internet users and promoting global cooperation. Tanzi (1996) Compliance unit has a positive relationship with and effect on money laundering and the activities of the international economy and international financial markets because the globalization of economic activities works to lowest the cost of anti-money laundering. According to Tanzi (1996) Although the facility with which dirty/money can now be laundered internationally this works to lower the cost of anti-money laundering Finally, Tanzi found a positive relationship between globalization e.i e-Government and money laundering, as well as some to the economic implications of large-scale money laundering. To combat money laundering cooperation between different financial institutions, especially banks and countries should be promoted. 
INTERNATIONAL JOURNAL OF ACADEMIC RESEARCH IN BUSINESS AND SOCIAL SCIENCES

Vol. 10, No. 2, Feb, 2020, E-ISSN: 2222-6990 @ 2020 HRMARS

\section{$\mathrm{H}_{3}$ : Compliance Unit has a Positive Impact on Money Laundering}

Cotterill (2001) Compliance unit through the implementation of e-government plays a vital role in countering the activities or effects of money laundry in the society. The compliance unit plays a mediating role between the e-Government and money laundering because it has to do with the IT, businessmen and woman all at the same time. E-Government work hand in hand with the compliance unit to fight corruption in the society and as well regulate the activities of money launderers. Compliance unit also can be referred to anti money laundry because it fights against money laundering and other crimes in the society, through the combinations of both cyber and non-cyber units in the countering of activities of money launderers through the impact of e-Government. Atkinson, (2003) Because E-Governance is the whole system involved in managing a society, thus it has a lot of positive influence on the phenomenon of money laundry via the mediating role of the compliance unit. The system includes activities not only by government organizations but also companies and voluntary organizations, and - often forgotten! "citizens". Moreover, it features the processes and flows of governance, dimensions that are critical to understanding the context of information systems deployment and use (Atkinson, 2003; (Al-Da'abseh, et al., 2018). For these reasons, e-Governance is a preferable term for use when considering IS applications to the public sphere. Clearly IT and information systems are at work in all the above activities. (Grönlund \& Horan 2005). E-government and Internet has made a lot of positive improvements in the whole society structure, values, culture and the ways of conducting business by utilizing the potential of ICT as a tool in the daily work. (Alshehri \& Drew, 2010).

Nardo (2011) explained; legal and illegal money market and considers them of equal size, volume and have a relationship existing between them and therefore they are interconnected, and thus, there is a small portion between them called semi-legal market. Legal and illegal markets work as the two alternatives available for the investors to decide which one to choose to earn profit. To regulate markets properly and to make them crime free, it is needful to establish a relationship with people working in the market and gather a strong database on its functionality and then use combating strategies to reverse the situation and introduce transparency in system and markets (Alwagfi et al., 2020).

\section{$\mathrm{H}_{4}$ : Compliance Unit Mediates the Relationship between E-Government and Money Laundering Methodology}

This cross-sectional study comprises three units; one independent variable, one dependent variable and the mediator whose impact is on money laundering. Banks are the major part of financial institutions which are vulnerable to money laundering because of the services and instruments provided by them to customers. Through the existing study, the researcher used the descriptive analytical method, to suit the nature of the existing study, as a method that collects data and information and describes the phenomenon and analyses. Where the reference to previous literature and relevant studies and relevance, and the researcher based on the tool, a questionnaire to collect data from members of the study sample. The study population consisted of all the employees of the Central Bank of Jordan: the Banking and Banking Control Section, members of the anti-money laundering unit. The number of employees' 142. The researcher distributed 140 questionnaires to the employees of the Central Bank, where they were chosen through a comprehensive survey 
INTERNATIONAL JOURNAL OF ACADEMIC RESEARCH IN BUSINESS AND SOCIAL SCIENCES

Vol. 10, No. 2, Feb, 2020, E-ISSN: 2222-6990 (C) 2020 HRMARS

method, and 132 and 9 were not valid for analysis, so that the sample is composed of 123 employees and employees.

\section{Study Results}

Below table 1 is a presenting the correlations, averages and standard deviations for each field of study and scale.

Table 1. Standard deviation, correlations and means among variables

\begin{tabular}{lccccc}
\hline \multicolumn{1}{c}{ Variables } & $\mathbf{1}$ & $\mathbf{2}$ & $\mathbf{3}$ & $\mathbf{M}$ & SD \\
\hline 1. E-government Application & 1 & $0.432^{* *}$ & $0.365^{* *}$ & 4.11 & 0.561 \\
2. Money laundering & $0.432^{* *}$ & 1 & $0.713^{* *}$ & 3.91 & 0.521 \\
3. Compliance Unit & $0.365^{* *}$ & $0.713^{* *}$ & 1 & 3.83 & 0.583 \\
\hline
\end{tabular}

$\mathrm{N}=363,{ }^{* *}$ correlations are significant at $p<0.001$.

In Table 1 are the (M, SD and CORRELATION) among variables. As was anticipated, E-government Application was positively correlated with the Money laundering ( $r=0.432)$, Also, positively correlated to Compliance Unit $(r=0.365)$. Moreover, Money laundering was positively correlated with Compliance Unit $(r=0.713)$. As a result, $\mathrm{H} 1, \mathrm{H} 2$, and $\mathrm{H} 3$ were receiving support by these results.

Below table 2 is a presenting the composite reliability (CR), Average variance extract (AVE) for each field of study and scale.

Table 2. Reliability; Composite reliability (CR), Average variance extract (AVE), Cronbach's $\alpha$ among variables.

\begin{tabular}{lccc}
\hline \multicolumn{1}{c}{ Variables } & $\begin{array}{c}\text { E-government } \\
\text { Application }\end{array}$ & $\begin{array}{c}\text { Money } \\
\text { laundering }\end{array}$ & $\begin{array}{c}\text { Compliance } \\
\text { Unit }\end{array}$ \\
\hline Composite reliability (CR) & 0.939 & 0.876 & 0.882 \\
Cronbach's $\alpha$ & 0.952 & 0.869 & 0.924 \\
Average variance extract & 0.632 & 0.511 & 0.611 \\
(AVE) & & & \\
\hline
\end{tabular}

Table 2 above check the reliability by Cronbach's alpha ( $\alpha$ ), and the results illustrated that $(\alpha)$ was above the threshold (0.60). Also, the convergent validity of the measurement mode was tested, and composite reliability (CR) had been found to be above the threshold (0.70) on the scale items (Hair, Anderson, Tatham \& Black,. 1998).in addition, the average variance extract (AVE) was above the threshold ( 0.50) (Fornell \& Larcker, 1981).

Below table 3 is a presenting the Confirmatory Factor Analysis (CFA) for each field of study and scale. 
INTERNATIONAL JOURNAL OF ACADEMIC RESEARCH IN BUSINESS AND SOCIAL SCIENCES Vol. 10, No. 2, Feb, 2020, E-ISSN: 2222-6990 @ 2020 HRMARS

Table 3. Confirmatory Factor Analysis

\begin{tabular}{|c|c|c|c|c|}
\hline Constructs & $\begin{array}{l}\text { Code } \\
\text { Item }\end{array}$ & Loading & $\mathbf{M}$ & SD \\
\hline \multirow{12}{*}{$\begin{array}{c}\text { E-government } \\
\text { Application }\end{array}$} & Q1_EGOV & 0.949 & 4.19 & .669 \\
\hline & Q2_EGOV & 0.941 & 4.16 & .680 \\
\hline & Q3_EGOV & 0.862 & 4.21 & .673 \\
\hline & Q4_EGOV & 0.696 & 4.15 & .676 \\
\hline & Q5_EGOV & 0.857 & 4.15 & .708 \\
\hline & Q6_EGOV & 0.74 & 4.05 & .751 \\
\hline & Q7_EGOV & 0.861 & 4.03 & .674 \\
\hline & Q8_EGOV & 0.586 & 4.07 & .721 \\
\hline & Q9_EGOV & 0.729 & 4.01 & .705 \\
\hline & Q10_EGOV & 0.822 & 4.09 & .675 \\
\hline & Q11_EGOV & 0.819 & 4.04 & .696 \\
\hline & Q12_EGOV & 0.782 & 4.15 & .688 \\
\hline Constructs & $\begin{array}{l}\text { Code } \\
\text { Item }\end{array}$ & Loading & $\mathbf{M}$ & SD \\
\hline \multirow{7}{*}{ Money laundering } & Q1_MLAU & 0.603 & 4.00 & .788 \\
\hline & Q2_MLAU & 0.923 & 3.94 & .675 \\
\hline & Q3_MLAU & 0.705 & 3.95 & .667 \\
\hline & Q4_MLAU & 0.584 & 3.85 & .696 \\
\hline & Q5_MLAU & 0.806 & 3.91 & .654 \\
\hline & Q6_MLAU & 0.591 & 3.90 & .697 \\
\hline & Q7_MLAU & 0.722 & 3.84 & .685 \\
\hline Constructs & $\begin{array}{c}\text { Code of } \\
\text { Item }\end{array}$ & Loading & $\mathbf{M}$ & SD \\
\hline \multirow{8}{*}{ Compliance Unit } & Q1_COMP & 0.833 & 3.86 & .643 \\
\hline & Q2_COMP & 0.848 & 3.90 & .689 \\
\hline & Q3_COMP & 0.758 & 3.86 & .710 \\
\hline & Q4_COMP & 0.734 & 3.80 & .756 \\
\hline & Q5_COMP & 0.767 & 3.83 & .720 \\
\hline & Q6_COMP & 0.757 & 3.75 & .757 \\
\hline & Q7_COMP & 0.742 & 3.80 & .764 \\
\hline & Q8_COMP & 0.785 & 3.82 & .726 \\
\hline
\end{tabular}

Furthermore, Table 3 Above shows CFA which was checked to analysis factor loadings (Browne\& Cudeck, 1993). The factor loadings varied from 0.58 to 0.94 , and all results revealed in Table above point to that all factor loadings were significant and satisfactory. Below table 4 is a presenting the Goodness of fit for the model for each field of study and scale. 
INTERNATIONAL JOURNAL OF ACADEMIC RESEARCH IN BUSINESS AND SOCIAL SCIENCES

Vol. 10, No. 2, Feb, 2020, E-ISSN: 2222-6990 @ 2020 HRMARS

Table 4. Goodness of fit for the model.

\begin{tabular}{ccc}
\hline Measurement Model & Structural Model & Cut-Off Points \\
\hline$\chi^{2}=751.625$ & $\chi^{2}=751.625$ \\
$\mathrm{Df}=319, p=0.000$ & $\mathrm{Df}=319, p=$ \\
$\mathrm{GFI}=0.846$ & $\mathrm{GFI}=0.864$ & "1 = perfict fit (Tanaka \& Huba, 1985)" \\
$\mathrm{NFI}=0.906$ & $\mathrm{NFI}=0.906$ & "1 = perfict fit [Bentler \& Bonett, 1980)" \\
$\mathrm{CFI}=0.943$ & $\mathrm{CFI}=0.943$ & "1 = perfict fit (McDonald \& Marsh, 1990)" \\
$\mathrm{RMSEA}=0.061$ & $\mathrm{RMSEA}=0.061$ & "Good fit < 0.08 (Browne \& Cudeck, 1993)" \\
$\mathrm{CMIN} / \mathrm{df}=2.356$ & $\mathrm{CMIN} / \mathrm{df}=2.356$ & "Good fit between 1 and 5 [Marsh \&. Hocevar, \\
$\mathrm{SRMR}=0.0476$ & $\mathrm{SRMR}=.0476$ & 1985)" \\
$\mathrm{CMP}=0.42$ & & "Good fit < 0.08 [Hu \& Bentler, 1990)" \\
& & "Does not affect study's data < 0.50 [Podsakoff, \\
\end{tabular}

Goodness of fit $=(\mathrm{GFI})$, comparative fit index $=(\mathrm{CFI})$, normed fit index $=(\mathrm{NFI})$, relative $\chi^{2(}$ $=\mathrm{CMIN} / \mathrm{df})$, root mean square error of approximation= (RMSEA), Standardized Root Mean Square Residual= (SRMR), Common method bias=(CMB).

The research checked the (proposed hypothesis) on CFA and SEM, with the AMOS program, to certify the "goodness of fit" of the recommended model. As exposed in Table 4, the structural model and measurement model were assessed applying the goodness of fit (Anderson \& Gerbing, 1988). Egovernment Application, Money laundering and Compliance Unit, the three latent factors enclosed in the measurement mode, and 27 indicators 12 items for E-government Application, 7 items for Money laundering, and 8 items for Compliance Unit). Table 4 proves that the measurement model illustrated a good fit.

The recommended model had been experienced and illustrated a good fit after verifying that the measurement model illustrated a good fit too, showing the following results in table 4 . When we applied "fully mediated model" it indicated a good fit to the data after being judged against to the "partially mediated model". (See table 4). This recommended model does not reach any provable improvement in fit more than the "partially mediated model" in spite of confirming to be a good fit to the data, which exhibits that when applying the "partially mediated model", E-government Application has a good and positively correlated effect on Money laundering. Since, the "partially mediated model" is a better fitting model for examining these data particularly in harmony with (Baron \& Kenny)'s procedure.

Below table 5 is a presenting the Total, direct, and indirect effects of the research variables for each field of study and scale. 
INTERNATIONAL JOURNAL OF ACADEMIC RESEARCH IN BUSINESS AND SOCIAL SCIENCES Vol. 10, No. 2, Feb, 2020, E-ISSN: 2222-6990 @ 2020 HRMARS

Table 5. Total, direct, and indirect effects of the research variables.

\begin{tabular}{|c|c|c|c|c|}
\hline "Exogenous Variables" & $\begin{array}{l}\text { "Endogenous } \\
\text { Variables" }\end{array}$ & $\begin{array}{l}\text { Total } \\
\text { Effect }\end{array}$ & $\begin{array}{l}\text { Direct } \\
\text { Effect }\end{array}$ & $\begin{array}{c}\text { Indirect } \\
\text { Effect }\end{array}$ \\
\hline $\begin{array}{l}\text { E-government } \\
\text { Application }\end{array}$ & Money laundering & 0.447 & 0.147 & 0.300 \\
\hline $\begin{array}{c}\text { E-government } \\
\text { Application }\end{array}$ & Compliance Unit & 0.392 & 0.392 & 0.000 \\
\hline Compliance Unit & Money laundering & 0.764 & 0.764 & 0.000 \\
\hline
\end{tabular}

These outcomes (as obtainable in Table 5) confirmed that the path coefficient between Egovernment Application and Money laundering s $(b=-0.432, p \leq 0.001)$ was positive and significant. It also clarifies $R^{2}$ (Money laundering) $=19 \%$ of the variance $(\mathbf{H} 1$ received support). The result showed that E-government Application affected Employee satisfaction in support of Hypothesis 2. $(b=0.392$, $p \leq 0.001$ ) It explains $R^{2}$ (Employee satisfaction) $=13 \%$ of the variance, so $\mathbf{H 2}$ received support. The impact of Employee satisfaction on the employee's Money laundering $(b=-0.764, p \leq 0.001)$ was positive and significant (H3 as predicted), and explains $R^{2}$ (Money laundering) $=51 \%$ of the variance (H3 received huge support). Hypothesis 4 forecasted that Employee satisfaction mediates the relationship between E-government Application Management and employee's Money laundering. The effect of E-government Application Management on Money laundering increased while also being significant and positive when Employee satisfaction (the mediator variable) was added to the model. The relationship between E-government Application and the employees' Money laundering had an indirect effect which was significant $(b=0.300, p \leq 0.001)$. Hypothesis 4 was supported, as the total effect of the relationship between E-government Application and the employees' Money laundering was significant $(b=0.447, p \leq 0.001$, so partially-mediated model received support according to (Baron \& Kenny, 1986)'s procedure.

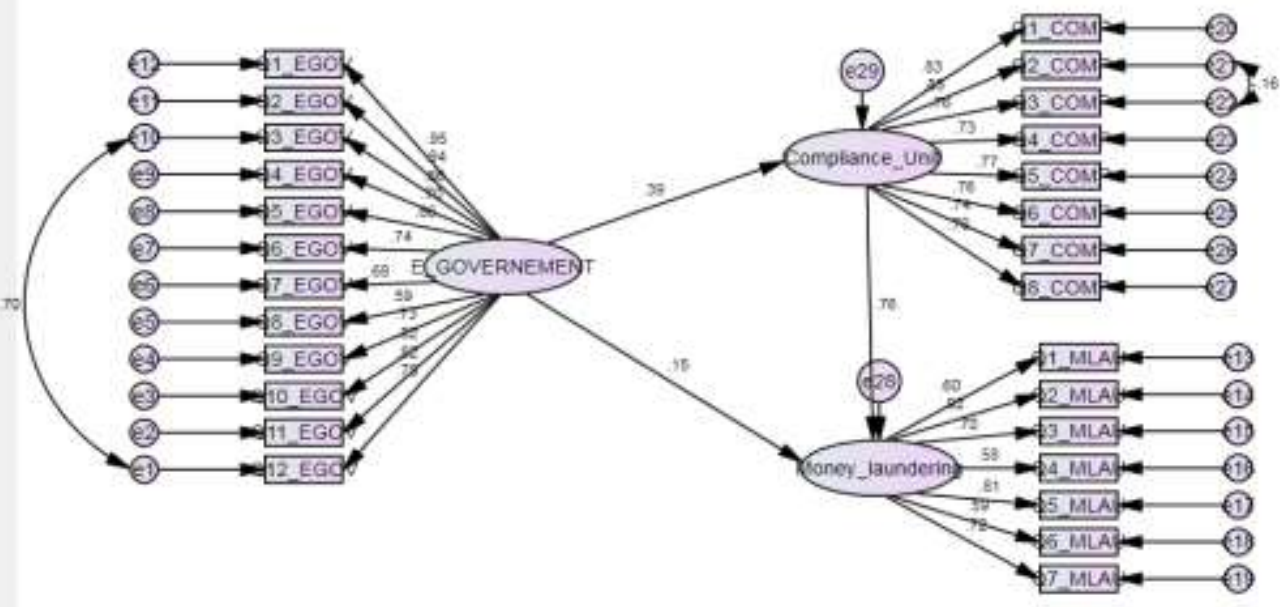




\section{Conclusion}

E-government has a positive impact on money laundering and compliance unit wherefore compliance unit has a positive impact on money laundering and also mediates the relationship between egovernment and money laundering, thereby resulting to a serious cohesion between e-government and all the variables. It is necessary and appropriate for the Internet to be a safe technical technique, achieving an acceptable degree of security on the network is one of the most important requirements to carry out its work, and become a problem of information security more specific to cash transfers in various forms (Ionescu, 2015). E-government is one of the modern concepts and technologies that have been associated with the revolution of information and communication technology, and their impact on the government sector and on this basis it provides government services to citizens and the business community, wherefore this study aimed at the proffering a solution whereby the compliance unit in conjunction and corporation with e-government can fight and combat money laundering.

The researcher justifies that e-government provides an opportunity for people to complete their governmental transactions electronically, which contributes to enhance government services and obtaining them electronically which also enable them to view information and complete the exchange between government agencies and the audience of their services through compliance unit at any time and place on the basis of justice, equality and honesty. This affects disclosure of the true source of funds deposited with the banking system and the statement of any false information that has been forged to give it legal status, especially compliance unit aims to empower the workforce and activate accountability with the parties concerned by making public sector employees more accountable for their decisions, which result in that limiting illegal and suspicious activities and close to legal accountability. It is worth noting that the phenomenon of money laundering is one of the forms of organized economic crime that aims to legalize funds and they are originally. It has an illegal source and is considered one of the most serious crimes of the modern economy era, which represents the real challenge for financial and business institutions.

\section{Implementation}

Implementation of digital technologies and e-processes will possibly result in large scale structural unemployment, thereby causing a large number of people not to be employed and this will require training and re-education for workers that will find themselves unemployed. Therefore, the government of the country must create an emergency plan to salvage the situation, considering roughly a quarter of its working population is employed in the public sector. Sensitive data that is stored on government services should also be encrypted and well protected from accidental or malicious dissemination. While the government has implemented e-government national strategies (such as the e-Government Strategy 2014-2016 and Reach 2025), the lack of cohesion and coordination between governments departments should be addressed (Mohammad, 2009).

\section{Recommendations}

Based on the results of the study, the researcher has made the following recommendations: The necessity of taking into consideration an effective application of all the principles and controls emanating from international organizations regarding combating money laundering operations. The necessity of working to establish controls to discover money laundering operations and keep abreast 
of developments in the field of information and communications technology, to enable money launderers to exploit these modern technologies and to identify methods and methods that money launderers can use and exploit. The necessity of establishing adequate administrative controls to uncover money laundering operations and fill gaps that can be exploited in this regard. The necessity of working to develop a commitment plan for all bank employees at various levels and their functional positions in the responsibility centers with the basic principles related to methods of combating money laundering in terms of preventing these operations from occurring and discovering them if they occurred. We invite scholars and researchers in this field to consider research in the field of money laundering as a phenomenon that spreads widely and its risks to the national economy.

\section{References}

Adu, K. K., Patrick, N., Park, E. G., \& Adjei, E. Evaluation of the implementation of electronic government in Ghana. Information Polity, (Preprint), 1-14.

Al-Da'abseh, T., Aljawarneh, N., \& Shwiyat, Z. (2018). Marketing Mix Startegies and Its Impact on Organizational Performance Efficiency in the Jordanian Company for Investment and SupplySafeway: An Empirical Study. Invention Journal of Research Technology in Engineering \& Management, 2(2), 14-23.

Al-Jawarneh, N. M. S. (2016). Case Study: Business Management School at the Turkish Republic of North Cyprus and how Strategic Thinking and Planning Can Improve the Performance of the Organization to Maintain Stable between Competitors.

Aljawarneh, N. M. S., \& Atan, T. (2018). Linking Tolerance to Workplace Incivility, Service Innovative, Knowledge Hiding, and Job Search Behavior: The Mediating Role of Employee Cynicism. Negotiation and Conflict Management Research, 11(4), 298-320.

Aljawarneh, N., \& Al-Omari, Z. (2018). The Role of Enterprise Resource Planning Systems ERP in Improving Customer Relationship Management CRM: An Empirical Study of Safeway Company of Jordan. International Journal of Business and Management, 13(8), 86-100.

Al-Omari, Z. S., Aljawarneh, N., Davut, S., \& Salah, A. (2018). The Impact of Marketing Mix Elements on Forming Mental Images about Islamic Banks in Jordan: An Empirical Study. OFFICIAL, 12, 54.

Al-Omari, Z., Alomari, K., \& Aljawarneh, N. (2020). The role of empowerment in improving internal process, customer satisfaction, learning and growth. Management Science Letters, 10(4), 841848.

Alshehri, M., \& Drew, S. (2010). Implementation of e-government: advantages and challenges. In International Association for Scientific Knowledge (IASK).

Alwagfi, A. A., Aljawarneh, N. M., \& Alomari, K. A. (2020). Work Ethics and Social Responsibility: Actual and Aspiration. Journal of Management Research, (12)1, 26-36.

Anderson, J. Y. G. D. W. (1988), "Structural equation modelling in practice: a review and recommended two-step approach". Psychological Bulletin, 103(3), 411-423.

Anthes, G. (2015). Estonia: a model for e-government. Communications of the ACM, 58(6), 18-20.

Aritonang, D. M. (2017). The Impact of E-Government System on Public Service Quality in Indonesia. European Scientific Journal, 13(35), 99-111. 
INTERNATIONAL JOURNAL OF ACADEMIC RESEARCH IN BUSINESS AND SOCIAL SCIENCES

Vol. 10, No. 2, Feb, 2020, E-ISSN: 2222-6990 @ 2020 HRMARS

Baron, R. M., Kenny, D. (1986). Moderator-Mediator Variables Distinction in Social Psychological Research: Conceptual, Strategic, and Statistical Consider ations. J. Personal. Soc. Psychol., 51, 1173-1182.

Bartlett, Christopher, A., anD Ghoshal. Managing across borders: The transnational solution. Harvard Business Press, 2002.

Bentler, P. M., Bonett, D. G. (1980). Significance tests and goodness of fit in the analysis of covariance structures. Psychol. Bull., 88, 588-606.

Browne, M. W., Cudeck, R. (1993) Alternative ways of assessing model fit. In Testing Structural Equation Models; Sage: Newbury Park, CA, USA, p. 136

Conyers, D. P. (2013). Impact of new bermuda anti-money laundering regime on investment fund operators and managers.

Daniali, G. (2014). E-money Laundering Prevention. New Marketing Research Journal, 4.

Danziger, J. N., \& Andersen, K. V. (2002). The impacts of information technology on public administration: an analysis of empirical research from the "golden age" of transformation. International Journal of Public Administration, 25(5), 591-627.

Darwazeh, R., Khraisat, D., \& Al Dajah, S. (2016). The effect of application of e-government on the staff performance in the Greater Amman Municipality a field study. Research in Business and Management, 3(2), 19-40.

Ereminaitè, S. (2014). The model of integration of electronic government and electronic business in public procurement. Regional Formation and Development Studies, 9(1), 39-51.

Haseena, F. M. L., \& Ragel, V. R. (2015). E-Government Readiness at Divisional Secretariats in Batticaloa District, Sri Lanka: Challenges and Recommendations. IUP Journal of Information Technology, 11(2).

Fornell, C., Larcker, D. (1981). Evaluating structural equation models with unobservable variables and measurement error. J. Mark. Res., 18, 39-50.

Gore, A. (1993). From red tape to results: Creating a government that works better and costs less: Report of the national performance review. Diane Publishing.

Grönlund, Å. \& Horan, T. A. (2005). Introducing e-gov: history, definitions, and issues. Communications of the association for information systems, 15(1), 39.

Hair, J., Anderson, R., Tatham, R., Black, W. (1998). Multivariate Data Analysis, 5th ed.; Prentice Hall: Upper Saddle River, NJ, USA,

Haruna, K., Ismail, M. A., Damiasih, D., Sutopo, J., \& Herawan, T. (2017). A collaborative approach for research paper recommender system. PloS one, 12(10).

Hu, L., Bentler, P. M. (1990). Cutoff criteria for fit indexes in covariance structure analysis: Conventional criteria versus new alternatives. Struct. Equ. Model. A Multidiscip.J., 6, 1-55.

Ionescu, L. (2015). The role of e-government in curbing the corruption in public administration. Economics, Management and Financial Markets, 10(1), 48.

Islam, M. S., Eva, S. A., \& Hossain, M. Z. (2017). Predicate Offences of Money Laundering and Anti Money Laundering Practices in Bangladesh Among South Asian Countries. Studies in Business and Economics, 12(3), 63-75.

Jun, K. N., Wang, F., \& Wang, D. (2014). E-government use and perceived government transparency and service capacity: Evidence from a Chinese local government. Public Performance \& Management Review, 38(1), 125-151. 
INTERNATIONAL JOURNAL OF ACADEMIC RESEARCH IN BUSINESS AND SOCIAL SCIENCES

Vol. 10, No. 2, Feb, 2020, E-ISSN: 2222-6990 @ 2020 HRMARS

Khrawish, H. A. (2014). The impact of anti-money laundering on investment funding: Evidence from Jordanian financial institutions. International Journal of Economics and Finance, 6(3), 227238.

Levin, S. C., Gutierrez, F. H., Carroll, K., \& Alper, E. (2016). Anti-money laundering and sanctions compliance challenges for custody services. Journal of Securities Operations \& Custody, 8(4), 341-355.

Lucian, R. D. (2010). The Concept of Money Laundering in Global Economy. International Journal of Trade, Economics and Finance, 1(4), 354.

Marsh, H. W., Hocevar, D. (1985). Application of confirmatory factor analysis to the study of selfconcept: First- and higher-order factor models and their invariance across groups. Psychol. Bull., 97, 562-582.

McDonald, R. P., Marsh, H. W. (1990). Choosing a multivariate model: Non centrality and goodness of fit. Psychol. Bull., 107, 247-255.

Mohammad, H., Almarabeh, T., \& Ali, A. A. (2009). E-government in Jordan. European Journal of Scientific Research, 35(2), 188-197.

Nadu, T. (2014). Money laundering analysis based on time variant behavioral transaction patterns using data mining. Journal of Theoretical and Applied Information Technology, 67(1).

Ostasius, E., \& Laukaitis, A. (2015). Reference model for e-government monitoring, evaluation and benchmarking. Engineering Economics, 26(3), 255-263.

Othman, M. H., \& Razali, R. (2018). Whole of Government Critical Success Factors towards Integrated E-Government Services: A Preliminary Review. Jurnal Pengurusan (UKM Journal of Management), 53.

Podsakoff, P. M., MacKenzie, S. B., Lee, J. Y., \& Podsakoff, N. P. (2003). Common method biases in behavioral research: a critical review of the literature and recommended remedies. Journal of applied psychology, 88(5), 879.

Pok, W. C., Omar, N., \& Sathye, M. (2014). An Evaluation of the Effectiveness of Anti-money Laundering and Anti-terrorism Financing Legislation: Perceptions of Bank Compliance Officers in Malaysia. Australian Accounting Review, 24(4), 394-401.

Seo, J. W., \& Hasan, M. G. M. (2015). Where is e-governments in south asian countries? a comparative approach. South Asian Studies, 30(2), 7.

Sutopo, B., Wulandari, T. R., Adiati, A. K., \& Saputra, D. A. (2017). E-Government, Audit Opinion, and Performance of Local Government Administration in Indonesia. Australasian Accounting, Business and Finance Journal, 11(4), 6-22.

Tan, C. W., Benbasat, I., \& Cenfetelli, R. T. (2013). IT-mediated customer service content and delivery in electronic governments: An empirical investigation of the antecedents of service quality. MIS quarterly, 37(1).

Tanaka, J. S., Huba, G. J. (1985). A fit index for covariance structure models under arbitrary GLS estimation. Br. J. Math. Stat. Psychol., 38, 197-201.

Kemal, U. M. (2014). Anti-money laundering regulations and its effectiveness. Journal of Money Laundering Control, 17(4), 416-427. 